\title{
Qualitative Analysis Concerning Universal Basic Income - Perceptions in Portugal
}

\author{
Diamantino Ribeiro \\ CEFAGE-UE - Centre of Advanced Studies and \\ Training in Management and Economics of the \\ University of Évora, Portugal \\ António Pedro Costa \\ University of Aveiro, Portugal \\ João Filipe Ribeiro \\ UBI - University of Beira Interior, Covilhã, Portugal
}

\begin{abstract}
The economic and social debate has been intensifying globally as a result of concerns about the increase in poverty in the world and the progressive separation between rich and poor. There is an urgent need to find ways and alternatives that can be tested and put into practice. This is an exploratory study on the perception of the Portuguese regarding Unconditional Basic Income or Universal Basic Income (UBI). UBI has defenders and opponents, both parties with convincing arguments about its practical applicability, however, conclusions cannot be reached without experience in the field and convincing results. Likewise, the idea should not be abandoned without understanding its real applicability, as its success could be important for the future development of the world. Studies on the UBI are still in their infancy. Therefore, Portugal's contribution to the enrichment of knowledge within the topics of "the future of work" and "work of the future" and, more specifically, about UBI, is seen as urgent. In this context, we prepared and analysed a survey, having obtained 273 valid responses. The results of the qualitative analysis on which this study focuses allow us to infer that there are still many flaws in the management and leadership of human resources and, among other aspects, that, in general, the respondents would prefer to work even though they might eventually receive a UBI.
\end{abstract}

Keywords: development, future, unconditional or universal basic income, work 


\section{Introduction}

The word "trabalho" ("work" in Portuguese) comes from the Latin tripalium, which means punishment. Tripálio (from the late Latin "tri" (three) and "palus" (stick) literally, "three sticks") is a Roman instrument of torture, to which slaves were subjected. Hence the verb in vulgar Latin tripaliare, which initially meant to torture someone on the tripálio. This instrument made of three sharp sticks, sometimes still equipped with iron spikes, would also serve for farmers to beat the wheat and ears of corn, to separate and fray them. These terms gave rise to, in Portuguese, the words "trabalho" and "trabalhar" (to work), although in the original sense the "trabalhador" (worker) would be the executioner, and not the alleged "victim", as is the case today.

Based on the concepts of slave labour, servility or a change in the paradigm from the industrial revolution, a historical context was developed with the main objective of understanding how the (possible) myth about compulsory labour (wage-labour) took root in the industrial revolution, complemented by the contributions of Karl Marx in his essays "Wage-Labour and Capital".

The philosopher Hannah Arendt in her work "The Human Condition" studied and interpreted the structures that condition the human experience, investigated the meaning and the modes of human activities and their respective dignities. For Arendt, work is an activity that man imposed on his own species, that is, it is the result of a cultural process (Arendt, 2010).

Governments of several countries concerned about the future of work and the predictable social changes that the changes may cause, have been discussing the possibility of implementing a basic and unconditional income for all citizens.

Finland was the first country in Europe to implement (in 2017) an idea close to UBI, which consisted of paying a group of unemployed people 560 euros per month, without conditions or demanding anything in return. The experience, limited to two years, covered two thousand unemployed people, but was abandoned by the Government. The pilot project ended without having achieved the desired results. Olli Kangas, an expert involved in the project, said: "Two years is a too short period to be able to draw definitive conclusions from such a valuable experience. We should have had more time and more money to achieve reliable results" ${ }^{1}$.

Defenders of UBI want to grant state support capable of ensuring a dignified life for all citizens. UBI is a regular fixed payment of money provided by the government - or another institution in the public sphere - to each citizen or resident, regardless of whether the individual is rich or poor and/or in a paid employment. This income is based on three characteristics (Van Parijs, 2004):

\footnotetext{
${ }^{1}$ The project covered unemployed people aged between 25 and 58 . Retrieved from: https://www.demoshelsinki.fi/en/2016/08/30/thousands-to-receive-basic-income-in-finland-a-trial-that-could-lead-to-the-greatest-societaltransformation-of-our-timel. Accessed on: 30/09/2019
} 
Universality: it must encompass the entire population;

Individuality: it must be designed to serve individuals, not families, since it is considered a truly individual right;

Unconditionality: it must be unconditional (or employ conditions that do not violate inclusion).

In a changing world, where the reality of work is changing due to automation, there are those who believe that UBI makes perfect sense. With the granting of this support, the State could ensure living conditions for its citizens, preventing the growth of political populisms, allowing everyone to share the success of a "new economy" (Birnbaum, 2012; FitzRoy \& Jin, 2018; Huws, 2017; Pereira, 2017a, 2017b; Widerquist, 2001; Yunker, 2013).

For some authors, work arises from humans' need to satisfy their needs and survive, while for others work is the activity developed by humans, under certain forms, to produce wealth (Chandra, Chandra, \& Pasma, 2010; Frank, 2008; Jordan, 2010; Pech, 2010). There are, however, several authors who contest UBI, reflecting and presenting studies with the aim of demonstrating that it is not a reasonable option (Altman \& Markham, 2019; Aydinonat, 2015a; Denniss \& Swann, 2016; Kaighin, 2019; Mays, 2016; Quiggin, 2019; Van Donselaar, 2009; Widerquist, 2018).

This work intends for the reflection to not be limited to the UBI, to its pros or cons, defenders or critics. Rather it is intended that it be seen in a broader perspective, taking into account the inevitability of changes in the "work of the future" and the "future of work".

\section{Theoretical framework}

\section{Evolution of work}

The denomination of work first appeared in the Bible, in the book of Genesis, when it referred to the division of tasks between men and women; men would be responsible for hunting and guaranteeing protection, and women for fulfilling domestic duties, as well as educating and caring for offspring. After the Neolithic period, and the development of animal husbandry and agriculture, manual labour was constantly devalued. In classical Greek philosophy, work was seen as a punishment, that is, it was inherent in negative thinking, although there are two theories about it: one related to the fact that work is considered the essence of man, created by those who practised it, and another, interconnected with the idea that work neglected and stifled human intelligence. Among thinkers in Ancient Greece, work was frowned upon. Aristotle put work in opposition to freedom, and Homer saw a desirable goal in the idleness of the ancient Greek nobility. Hard labour was for women, servants and slaves (Silva, 2016). In the Middle Ages, working in agriculture was an arduous task. Those who were obligated to practise forced labour by their employers had no choice. But whoever had the choice, preferred leisure and festivity and not worrying about tomorrow. 
Thinking of some kind of profit was considered an addiction. A quota of up to one hundred days off per year served to ensure that work was not in the foreground ${ }^{1}$. In the 16th century, Martin Luther declared idleness a sin. Man was born to work, Luther wrote. According to him, work is a "divine service" and at the same time "vocation" (Silva, 2016). In Anglo-American Puritanism, work was seen as a sign that whoever did it was chosen by God. This philosophy accelerated the development of capitalism (Guilherme De Moura \& Florianópolis, 2006). In the 18th century, the time of industrialisation in Europe, the population grew and the cultivable space decreased. People migrated to cities in search of work in factories and foundries. In 1850, many workers worked 14 hours a day, six days a week. Wages were barely enough to survive. Discoveries such as the steam engine and the loom tripled production (Burns, 2011). In the early 20th century, Henry Ford perfected work on the automotive industry's assembly line, setting standards for the industry in general. With that, the production of the Ford Model T in series, reduced the costs, which on the one hand lowered the sale price of the vehicle and on the other hand enabled higher salaries to the employees ${ }^{2}$. With the factories a new class appears: the proletariat. For Karl Marx, who coined this term, work is the essence of man. The socialist Paul Lafargue, son-inlaw of Carl Marx, said in 1880 that a strange addiction dominated the working class in all countries; he referred to the "love" of work and classified it as a frantic addiction, responsible for leading individuals to exhaustion (Henrique \& Mota, 2016). Throughout the 20th century, social costs for workers in the world's richest nations have increased significantly. As a result, companies have moved production to where labour is cheaper. In many poor countries, circumstances that are reminiscent of the beginning of industrialisation in Europe still prevail: child labour, low wages and a lack of social security. Meanwhile, in Europe jobs are increasing in the service sector. Elderly caregivers are desperately wanted. New fields of work are opening up as a result of social changes and technological advances. Over time, the workday was reduced and the volume of work per capita decreased by 30\% between 1960 and 2010 (Ursula Huws, 2016). Then there is robotization; machines do not strike, do not demand salary increases and are extremely thorough: industrial robots are revolutionising the world of work.

The American economist Jeremy Rifkin argues that we are experiencing an industrial revolution that will end wage-labour. Will the Robots replace us? This question has been asked for 40 years, since automation arrived at the factories, but now the situation intensifies the debate. With the advancement of digitalisation, the Internet of Things and the Industrial Internet of Things 4.0 (Fourth Industrial Revolution), many occupations are becoming "obsolete" - and not only in industry (Rifkin, 2014). Seen from a positive point of view, if machines do the work normally under the responsibility of humans, people now have time for other tasks such as environmental

\footnotetext{
${ }^{1}$ Retrieved from: http://www.amaso.com.br/PDFs/AMASOn18.pdf. Accessed on: 30/09/2019

${ }^{2}$ Retrieved from: https://www.ford.pt/experiencia-ford/historia-e-herenca. Accessed on 30/09/2019
} 
protection, support for the elderly, sick and needy, many tasks that are already being performed at the moment by volunteers. Maybe in the job market of the future, people can go back to doing what they like and what gives them pleasure? The question remains.

Dani Rodrik (2015), professor of International Political Economy at the John F. Kennedy School of Government, Harvard, and author of "Economics Rules: The Rights and Wrongs of the Dismal Science", argues that there is good and bad news for the future of work in developing countries. Thanks to social policies and labour rights, workers can become full players in the economy much earlier in the development process. At the same time, the traditional engine of economic development industrialisation - is likely to operate at much lower capacity. The resulting combination of high public expectations and low growth production capacity will be a major challenge for all the developing economies in the world (Aydinonat, 2015a).

With all these transformations happening at a speed that can make predictions difficult, in addition to it being necessary to take maximum advantage of the differentiating competences of the human being, especially our creative and innovative side in order to develop alternatives, it is also necessary to think beyond the normal; Bill Gates, for example, launched the idea of charging a fee for users and implementers of robotics, which in parallel can provide an income for citizens ${ }^{1}$.

\section{Unconditional Basic Income (UBI)}

The idea of an Unconditional Basic Income for the poor emerged in the 16th century, defended by humanist thinkers Thomas More and Ludovicus Vives. Thomas More defended the idea in his book Utopia in 1516 (More, 2014), curiously by the voice of a Portuguese traveller, Raphael Nonsenso, but it is Ludovicus Vives in 1526 who in his book "De Subventione Pauperum" defends the idea in more detail (Vives, 2017). In the 18th century, the idea of an income paid at once to all was defended by the Marquis de Condorcet in his posthumous book entitled "Esquisse d'un tableau historique des progrès de l'esprit humain" (Condorcet, 1795) and shortly after (1796) by his friend Thomas Paine in his book "Agrarian Justice" (Foner, 1995). This idea of income paid at once was also defended by two law professors at Yale University, Bruce Ackerman and Anne Alstott, in the book "The Stakeholder Society" (Ackerman \& Alstott, 1999) and is now widely discussed by other authors, as can be read in the book "The Ethics of Stakeholding" (Dowding, Wispelaere, \& White., 2003). In the 19th century, the idea of an Unconditional Basic Income that is defended is that which combines the two previous ideas - that of a basic income for the poor, with the idea of an income paid at once to everyone. This idea was defended by several distinguished thinkers, among them, the French utopian Charles Fourier in his book "La Fausse Industrie" (Fourier, 1836), the 19th century English political thinker and philosopher,

${ }^{1}$ Retrieved from: https://www.ft.com/content/d04a89c2-f6c8-11e6-9516-2d969e0d3b65. Accessed on 30/09/2019 
John Stuart Mill in his 1848 book "Principles of Political Economy" (Mill, 2006), and the Belgian Joseph Charlier) who defends the idea in his book "Solution du probleme social or constitution humanitaire (Charlier, 1848).

\section{In the 20th century, there were three periods in which the UBI was defended}

First, it was during the period between the two great world wars, mainly in Great Britain, with the philosopher and mathematician Bertrand Russell, the first to do so in his book "Roads to Freedom" published in 1918, (Russell, 2004), followed by economist George DH Cole in several of his books (Pound, Davis, \& McWhirter, 2015), and by economist James Meade, winner of the Nobel Prize in Economics, in his book "Outline of an Economic Policy for a Labour Government" published in 1935, (Blankenagel, 2012).

In the 60-70s, the debate took place mainly in the USA, where two of its most famous defenders and both Nobel Prize winners in Economics, Milton Friedman, and James Tobin, emerged (Friedman, 2009; Tobin, 1980). Other prominent figures showed themselves to be in favour of UBI, such as Martin Luther King and American President Richard Nixon (Marcelo, Merrill, Bizarro, \& Pinto, 2019).

Since the 1980s, the UBI was mainly defended in continental Europe, particularly through the creation, in 1986, of the BIEN (Basic Income European Network) based at the Catholic University of Louvain, with Belgian philosopher Phillipe Van Parijs, Head of Hoover Chair, and one of its most active founders. Since 2004, BIEN has come to mean Basic Income Earth Network.

At present, the debate is moving forward and backward, with defenders and opponents settling their arguments. It is expected that the debate will leave the academic circuit and be shared with citizens so that they can reflect, discuss and consolidate their ideas.

\section{Universal Basic Income (UBI) in Portugal}

In Portugal, the existence of a movement organised around the defence of a UBI is very recent. Until today, the experience that exists in Portugal closest to a UBI is the payment of a Guaranteed Minimum Income, created during the socialist government of António Guterres (1999 to 2002). Currently, it is called Social Insertion Income (RSI) and consists of the payment of a minimum income to all individuals who do not integrate in the work and social livelihood circuit. The bibliography produced in Portugal is almost non-existent, but there is some activity and ideas on the subject, mainly reflected on the website: $w w w$.rendimentobasico.pt.

Martim Figueiredo (2013) in his book "Será que os surfistas devem ser subsidiados?" (Should surfers be subsidised?) presents some reflections (Figueiredo, 2013). Roberto Merrill presented an article entitled "O Rendimento Básico Incondicional como um novo direito humano?" "Da exploração à pré-distribuição" (Basic Unconditional Income as a new human right? From exploration to pre-distribution), 
published on the website Esquerda.net, in which he develops a normative defence of the UBI ${ }^{1}$. In 2017, the 17th BIEN Congress was held in Portugal, as a way to encourage debate on the topic of UBI, with the participation of several speakers, researchers and academics and the presentation of articles ${ }^{2}$. Two years before the aforementioned congress, several public figures addressed their arguments in the media. Francisco Louçã, a politician with a left-wing ideology and a university professor, criticised the UBI saying that "it is strangely unfair, because it pays the same to the poor and the rich, and it is poorly reasoned, because it does not propose any consistent way of paying the bill" 3 ; this position was immediately criticised by several defenders of the UBI such as Roberto Merril, spokesman of the campaign in favour of UBI, who accused him of being "a right-wing guy", also by André Barata, leader of the Livre Party, who compared him to a modern-day slave trader, and José Neves, a defender of the UBI, who criticised him for outright refusing the idea without wanting to discuss it. Louçã supports his concerns by saying " $(. .$.$) if it is a commitment that should be left to the$ State and to be paid by all, then the minimum in this debate is for us to evaluate the feasibility, costs, effects and ways of proceeding" 4 . However, in the initiative for the European petition ${ }^{5}$ on the possible implementation of the UBI within the European Union, one of the UBI's responses would be to simplify social security systems, concentrating all social support, namely unemployment benefit, social reintegration allowance, family allowance, etc., in a single social support. For sociologist Adriano Campos and party leader Ricardo Moreira, giving up the requirement of full employment is announcing the death of the right to work ${ }^{6}$; they also accuse that " $(. .$. the proposers of the UBI refuse the utopian nature of the proposal, claiming its full application as a real and effective possibility, but in doing so they are entangled in a narrative that denies the most immediate of possibilities: the creation of jobs"7. Turning to the Austro-French philosopher André Gorz, Adriano Campos and Ricardo Moreira say that "it is important to understand the extent to which the notion of abstract work - the pillar of the theory of value/work - will have to be updated in order to provide a more accurate analysis of new forms of labour exploitation, at a time when the social cost of labour is increasingly moving away from the market measure of its immediate cost. The hypothesis of the disappearance of work is therefore not to be confused with the search for a better analysis of its crisis in the

\footnotetext{
${ }^{1}$ Retrieved from: https://www.esquerda.net/dossier/rendimento-basico-incondicional-2/33969. Accessed on: 01/10/2019

2 Retrieved from: http://rendimentobasico.pt/17o-congresso-bien/ Accessed on 01/10/2019

${ }^{3}$ Retrieved from: https://blogues.publico.pt/tudomenoseconomia/2015/03/02/rendimento-basico-incondicional-como-quanto-e-paraquem/ Accessed on: 10/10/2019

${ }^{4}$ Retrieved from: https://blogues.publico.pt/tudomenoseconomia/2015/03/02/rendimento-basico-incondicional-como-quanto-e-paraquem/ Accessed on: 25/10/2019

${ }^{5}$ Retrieved from: https://www.grundeinkommen.de/content/uploads/2011/10/11-10-09-mindesteinkommen-grundeinkommen-europaen.pdf Accessed on: 11/10/2019

${ }^{6}$ Retrieved from: https://www.esquerda.net/dossier/rendimento-basico-incondicional-1/33951. Accessed on: 11/11/2019

${ }^{7}$ Retrieved from: https://www.esquerda.net/dossier/rendimento-basico-incondicional-1/33951\#sdfootnote3sym. Accessed on: $11 / 11 / 2019$
} 
commercial and capitalist way of our times "1. In 2019, Gonçalo Marcelo, Roberto Merrill and Sara Bizarro, presented the book "Rendimento Básico Incondicional: uma defesa da liberdade" (Basic Unconditional Income: a defence of freedom) in order to, in their words, make an old idea known, in detail but accessible to the general public, but which has had a renewed interest in recent years (Marcelo et al., 2019).

From the brief framework carried out, it can be inferred that in addition to the reflections and debates on UBI in Portugal being recent and reduced, there are still many doubts about those who have already thought, reflected and discussed the topic. It was in this context that it is important to investigate the topic and, in particular, about the perception of ordinary Portuguese citizens. Namely, on the one hand whether you have heard of the UBI and, on the other hand, what your possible stance is on various issues about current and future work and about the implementation of the RBI.

\section{Experiences and work on UBI in the World}

Some restricted and inconclusive experiences took place in India and Namibia. In 2012 in India, for a year and a half, only for some villages in the state of Madhya Pradesh in which around 200 rupees per month (2.74 euros) and 100 rupees for children were allocated. In Namibia, between 2008 and 2012, approximately 10 euros per month was allocated to around 1200 inhabitants.

In turn, in Switzerland, a group of protesters and apologists of the UBI, who, with the justification that the unemployment level would increase with the replacement of humans by robotics, due to the progression and acceleration of technological development, gathered 126 thousand signatures to be delivered to Parliament in order to change the constitution and implement the UBI. In 2016, there was a referendum to propose the implementation of a UBI of 2,500 Swiss francs per adult and 625 francs for every minor under 18 years old. The measure was rejected by a wide margin; $76.9 \%$ of voters opposed the idea. Albert Jörimann, in his article "Financing Basic Income in Switzerland, and an Overview of the 2016 Referendum Debates" presents some studies to determine the real static cost of introducing UBI in Switzerland, analyses the available funding resources, and assesses the benefits of social security, pointing out several issues and concerns with its sustainability (Jörimann, 2017).

Finland was the first country in Europe to test the allocation of a universal basic income in the year 2017, allocating $€ 560$ to two thousand unemployed people, aged between 25 and 58 years old, every month, with no obligations or compensation on their part. After 2 years of implementation, the Government ended the experiment. Olli Kangas, an expert involved in the project, said: "Two years is a too short period to be able to draw definitive conclusions from such a valuable experience. We should

${ }^{1}$ Retrieved from: https://www.esquerda.net/dossier/rendimento-basico-incondicional-1/33951\#sdfootnote6sym. Accessed on: $11 / 10 / 2019$ 
have had more time and more money to guarantee reliable results"1. The conclusions were disappointing for those who believed that the UBI would be a good strategy with regard to increasing employment. According to the preliminary results of the study (Fig.1), people who received UBI had more half-days employed for an entire year, compared to what happened in an identical group of unemployed (control group) who did not receive this benefit. Those on the pilot test were employed for 49.6 days in 2017. Those in the control group worked for 49.3 days. "We can say that during the first year of the experiment, those who received the UBI were neither better nor worse than those in the control group," said Ohto Kanninen, one of the people in charge of the pilot test ${ }^{2}$. If they got a job, UBI beneficiaries would continue to receive the benefit; on the other hand, they had no penalty if they did not actively seek employment, or refused offers that arose.

\section{Figure 1 - Effects of UBI on employment (Finland 2017 experience)}

\begin{tabular}{|c|c|c|c|c|}
\hline & $\begin{array}{l}\text { Treatment } \\
\text { group }\end{array}$ & $\begin{array}{l}\text { Control } \\
\text { group }\end{array}$ & Difference & p-value \\
\hline \multicolumn{5}{|l|}{ Employment status } \\
\hline Days in employment (number of days) & 49.64 & 49.25 & 0.39 & \multirow[t]{9}{*}{0.87} \\
\hline $\begin{array}{l}\text { Persons with earnings or income from self-employment } \\
\text { (\%) }\end{array}$ & 43.70 & 42.85 & 0.85 & \\
\hline Earnings and income from self-employment, total (€) & 4,230 & 4,251 & -21 & \\
\hline \multicolumn{4}{|l|}{ Benefits provided by Kela $(€)$} & \\
\hline Unemployment benefits & 5,852 & 7,268 & -1415 & \\
\hline Social assistance & 941 & 1,344 & -403 & \\
\hline Housing allowance & 2,525 & 2,509 & 16 & \\
\hline Sickness allowance & 121 & 216 & -96 & \\
\hline Number of observations & 2,000 & 173222 & & \\
\hline \multicolumn{5}{|c|}{$\begin{array}{l}\text { Note: (i) The days in employment are based on data on accrual periods from the Finnish Centre for Pensions. Days } \\
\text { of employment are defined as periods in the open labour market for which the calculated daily wage amounts to at } \\
\text { least } 23.74 \text { euros; (ii) The percentage who have received earnings or income from self-employment and their num- } \\
\text { ber is based on data from the Finnish Tax Administration; (iii) The data on benefits provided by Kela is based on } \\
\text { data from Kela's benefit register; (iv) The p-value shows the level of significance at which the equality of the aver- } \\
\text { ages for the treatment group and the control group can be cancelled out. Typically the difference between the } \\
\text { groups is considered statistically significant when the p-value is } 0.05 \text { or smaller. }\end{array}$} \\
\hline
\end{tabular}

\section{Source: Kela - The Social Insurance Institution of Finland}

If the impact on employment was negligible, the UBI ended up improving the wellbeing of the people included in the test (Fig.2). "The UBI beneficiaries in the pilot test reported better levels of well-being in all criteria, compared to what was reported in the comparison group", says another person in charge of this test, Olli Kangas ${ }^{3}$.

\footnotetext{
${ }^{1}$ Retrieved from: https://expresso.pt/internacional/2018-04-23-Finlandia-acaba-com-a-experiencia-de-rendimento-basico-universal. Accessed on: $15 / / 11 / 2019$

${ }^{2}$ Retrieved from: https://www.sabado.pt/ultima-hora/detalhe/rendimento-basico-incondicional-nao-ajudou-a-criar-emprego-na-finlandia. Accessed on: 15/11/2019

${ }^{3}$ Retrieved from: https://www.jornaldenegocios.pt/economia/seguranca-social/detalhe/rendimento-basico-incondicional-nao-ajudou-acriar-emprego-na-finlandia. Accessed on: 15/11/2019
} 


\section{Figure 2 - Effects of UBI on Well-Being (Finland 2017 experience)}

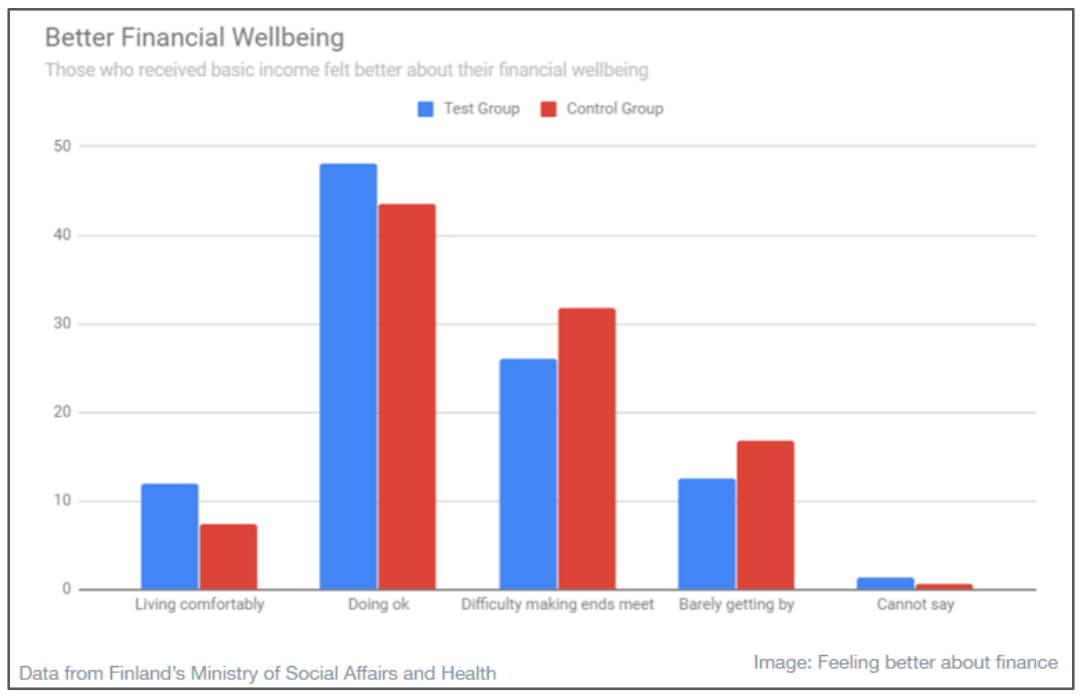

Source: Finland's Ministry of Social Affairs and Health

The people included in the test showed "fewer stress symptoms, fewer concentration difficulties and fewer health problems," said Minna Ylikanno, a researcher who was also involved in this experiment. Beneficiaries "were also more confident in the future," he added 1 . Finland is seen as a model country in social support policies, especially with regard to education and encouraging births; the northern European country, one of the oldest in the region, has experienced solid economic growth and has managed to lower the unemployment rate in recent years. The rate dropped to $6.6 \%$ in December 2018, which corresponds to the lowest level in 10 years. In parallel to the various experiences that are emerging, several researchers have followed and supported reflections worldwide:

In Australia, Altman, (2016) and Altman \& Markham, (2019) studied the application of a basic income for indigenous Australians in a subsistence approach in neoliberal times and the reasons for the failure of the Government's goals to halve the difference in results employment between indigenous and other Australians by 2018. In the year 2016, Greg Marston, asks the question whether the UBI can play an important role in the future and answers in his article "Greening the Australian Welfare State: Can Basic Income Play a Role? In Basic Income in Australia and New Zealand" (Marston, 2016). Gary Flomenhoft (2017), in his article "Total Economic Rents of Australia as a Source for Basic Income" presents an approach to UBI establishing a link with artificial intelligence (AI), defending the urgency to resolve the issue of how to finance the UBI

\footnotetext{
${ }^{1}$ Retrieved from: https://www.sabado.pt/ultima-hora/detalhe/rendimento-basico-incondicional-nao-ajudou-a-criar-emprego-na-finlandia. Accessed on: 15/11/2019
} 
(Flomenhoft, 2017). In a very recent approach, Tin Hollo argues that the implementation of UBI in Australia requires an examination of the political context and a political strategy to change the discourse and build power, which is why in his article "Finding a Political Strategy for a Basic Income in Australia", he describes the political context in Australia, analysing the positions of the main political parties and civil society organisations, proposing approaches to create support for Unconditional Basic Income (Hollo, 2019).

In South America, Alzúa, Cruces, \& Ripani, (2013) analysed the effect of 3 welfare programmes and incentives for work and the supply of adult labour in developing countries in rural areas: Mexico's National Education, Health and Nutrition Programme (PROGRESA), Nicaragua's Social Protection Network and the Honduras Family Allowance Programme and concluded that the effects that the programmes had on the labour supply of participating adults were mainly negative, but they are still small and are not statistically significant.

In the Netherlands, in 2019, Loek Groot, Ruud Muffels and Timo Verlaat, realising that the focus on state support for well-being has shifted from anti-poverty policies to social investment strategies, address the UBI and its motivational psychological perspectives and behavioural economics in his article "Welfare States' Social Investment Strategies and the Emergence of Dutch Experiments on a Minimum Income Guarantee" (Groot, Muffels, \& Verlaat, 2019).

In Ireland, following the serious financial crisis that shook the country in the early 2010s, concerns about future employment became one of the concerns and in this way we can see the emergence of some studies and proposals on the implementation of the UBI; Randall Wray, studies and presents some proposals in his article "The Euro Crisis and the Job Guarantee: A Proposal for Ireland" (Wray, 2013).

In Alaska, since the 1980s, the annual payment of a Permanent Fund dividend to all residents has been instituted, but its impacts on the economic, social and political scenario have never been studied; Scott Goldsmith, in his article "The Economic and Social Impacts of the Permanent Fund Dividend on Alaska" presents only a systematic reflection based on various observations, interpretations and research (Goldsmith, 2012).

In China, the topic of UBI is relatively new, but it could become relevant, especially in a post 2020 approach, when, despite the projected eradication of extreme poverty at the national level, other forms of social challenges may arise or become more prominent. This can raise questions about current welfare policies and possible barriers to maintaining effective support for those in need. In this context, China has started a research project to discuss UBI. According to promoters, the goal is to start exploring the potential of UBI as an alternative political tool to provide social protection, based on theoretical discussions about the pros and cons of UBI, as well 
as an overview of its current or expected practices (Zhen, Guerriero, Lopez, \& Haverman, 2020).

Finally, it is also interesting to refer to the vision of UBI and its future impacts on the perspective of gender equality, shared by Eva Cox, in her article "Feminist Perspectives on Basic Income" where she demonstrates concerns regarding the integration of women in future work (Cox, 2019).

\section{Methodology}

In order to investigate the perception of the Portuguese about "the future of work" vs "the work of the future" and its relationship with UBI, an online survey was created on the Google Drive platform. 273 individuals participated in the survey. All responses were considered valid. After the profiling of the participants (sex, age, marital status, workplace and profession), 21 closed questions for quantitative assessment and 4 'open' questions for qualitative analysis were asked. In this study, the answers to the 4 open questions are analysed:

If you work. If your hours were cut in half, without reducing your pay, what would you do in the remaining hours?

If you work. For some people, work is simply a means of "earning a living"; for others it means much more than that. What about you?

If you work. What amount of money would allow you to stop working?

If you work. What was the most useless task (job) you have ever performed in your professional life?

In complementary studies, other variables will be analysed, such as knowledge about UBI, the position regarding the application of UBI in Portugal, the opinion about the increase in the minimum wage, about current work and the work of the future and the relationship between work and happiness.

\section{Data analysis}

To handle the answers to the open questions, the qualitative analysis software webQDA was used. WebQDA is a software to support the analysis of qualitative data in a collaborative and distributed environment; it is a software aimed at researchers, in different contexts, who need to analyse qualitative data, individually or collaboratively, synchronously or asynchronously. With webQDA, the researcher can edit, view, link and organise documents. Simultaneously you can create categories, code, control, filter, search and question the data in order to answer the questions that emerge in your investigation (Costa, 2016; Costa \& Amado, 2018; Costa, de Sousa, Moreira, \& de Souza, 2017; Costa, de Souza, Moreira, \& de Souza, 2018; Costa, Linhares, \& de Souza, 2014; Costa, Moreira, \& Souza, 2019). From our point of view, qualitative research aims to develop an understanding of the context in which phenomena and behaviours occur and, for this reason, we believe that qualitative 
approaches can be complementary to quantitative studies. Altinay \& Paraskevas (2008) also indicate that the qualitative approach is based on an inductive model and on phenomenology.

\subsection{Characterisation of the sample}

The total sample consists of 273 participants (Table 1); the majority of respondents are female (66.9\%) and 57.4\% were between 36 and 67 years old; about half of the respondents were married or in a non-marital partnership (50.4\%); $90.4 \%$ of the sample were workers, with $71 \%$ working for others.

\section{Table 1 - Distribution of sociodemographic variables}

\begin{tabular}{|llll|}
\hline & & $\mathrm{n}$ & $\%$ \\
\hline Gender & Male & 90 & 33.1 \\
& Female & 182 & 66.9 \\
\hline Age & $\leq 18$ years & 4 & 1.5 \\
& 19 to 25 years & 51 & 18.8 \\
& 26 to 35 years & 50 & 21.7 \\
& 36 to 49 years & 91 & 33.5 \\
& 50 to 67 years & 65 & 23.9 \\
& $>67$ years & 2 & 0.7 \\
\hline Marital Status Single & 105 & 38.6 \\
& Married/ Non- & & \\
& marital & & \\
& partnership & 157 & 50.4 \\
& Divorced & 28 & 10.3 \\
& Widower & 2 & 0.7 \\
\hline Occupation & Employed & 246 & 90.4 \\
& Student & 26 & 9.6 \\
\hline Type of & Self-employed & 50 & 18.4 \\
contract & Selond & 193 & 71.0 \\
& Dependent & \\
& employment & & \\
& Unemployed & 29 & 10.7 \\
\hline
\end{tabular}

\subsection{Analysis of the findings}

The results obtained with the support of the software for home are presented below, one of the open questions posed to the respondents.

\subsubsection{Question 1: If you work. If your hours were cut in half, without reducing your pay, what would you do in the remaining hours?}

The data obtained shows that $21.8 \%$ of the respondents report that they would use the available time to dedicate to their family and friends, $21.5 \%$ would dedicate more time to their hobbies and leisure activities, $15.5 \%$ would choose to use the time on their training and $13.9 \%$ report that they would take advantage to practice more sport and physical exercise. It should also be mentioned that $9 \%$ of respondents, if they had more time available, would choose another job, $6.8 \%$ would dedicate more time to themselves and their personal life, 5.2\% would dedicate the time to volunteering and $3.5 \%$ chose that they would simply rest The analysis of the answers 
to the first question, by sex of the respondents, shows that female individuals would primarily spend more time with family and friends $(22.6 \%)$, followed by Hobbies and Leisure activities (21\%) and training (14.3\%). Regarding male individuals, the order of priorities is different: first, they would choose to dedicate more time to hobbies and leisure activities (22.6\%), followed by family and friends $(20 \%)$ and thirdly, they would dedicate more time to their training (18.3). In addition to these three items, which represent more than $50 \%$ of the sample in both sexes, especially $13.9 \%$ of the sample, which also refers to dedicating more time to physical exercise and sport. On the other hand, only $9 \%$ said they would find another job and $5.2 \%$ would volunteer. They report that they would dedicate more time to themselves and their personal lives, $6.8 \%$, and $3.5 \%$ say they would use that free time to rest. The age analysis of the respondents shows that individuals aged between 19 and 25, of they had more free time, would favour training (33.3\%) while respondents between 26 and 35 would favour dedicating themselves to family and friends (32.6\%) as well as those aged between 36 and 49 years (28.1\%). Those aged 50 and over say that they would favour their hobbies and leisure activities. Regarding the analysis of the options for the use of free time, by respondents' marital status, $21.7 \%$ of single respondents said they would use it to invest in their training and $20.7 \%$ to their hobbies and leisure activities, married people say they would choose to dedicate more time to family in first place $(30.6 \%)$ and $20.2 \%$ would choose to increase the time they spend doing leisure activities and hobbies. Divorced people in turn respond that they would use the free time for their hobbies and leisure activities in first place (27.9\%), with $18.6 \%$ devoting more time to sport and exercise.

\subsubsection{Question 2: If you work. For some people, work is simply a means of "earning a living"; for others it means much more than that. What about you?}

Regarding the second question, 7 tree codes were created. The data shows that $15.2 \%$ of respondents only work because they need to earn money. Of the remainder, $13.1 \%$ say that it is effectively a way to make money, but not exclusively and still $24.1 \%$ of the respondents say that for them work is more than a way to make money. In addition to these generic responses, $23.8 \%$ of respondents say that work is part of their personal fulfilment, $8.2 \%$ like their work and $2.8 \%$ even say they love their work. Finally, $12.8 \%$ consider that work makes them feel useful to society. The analysis of the answers to the second question, by sex shows that there is a great proximity between sexes, in relation to work being simply a way of making money; $16.3 \%$ male and $14.8 \%$ female. There is also a great similarity in the percentage between women and men when they consider it a way to make money, but not just that. $40.7 \%$ of individuals say that for them work is more than a way to earn money in contrast to $16.8 \%$ of women. In addition to these three items, which represent more than $50 \%$ of the sample in both sexes, $27 \%$ female and $16.3 \%$ male consider that work is part of personal fulfilment. 
The age analysis of the respondents shows that individuals aged between 19 and 25 consider that work is a way of earning a living (27\%); respondents between 26 and 35 also consider it a way to earn a living (22.7), with an equal percentage considering that work is a form of personal fulfilment. Regarding the age group between 36 and 49 years old, only $8.2 \%$ consider that work is just a way to earn money, with $24.5 \%$ defining work as part of their personal fulfilment. The respondents aged 50 and over have a similar opinion; only $11.7 \%$ say that work is a way of making money; $29.9 \%$ consider work to be a form of personal fulfilment. Regarding the analysis by respondents' marital status, $26.6 \%$ of singles are of the opinion that work is only a way to earn money, while only $10 \%$ of married or unmarried partners and $15.7 \%$ of divorcees have the same opinion. For married people, work is more than a way to earn a living (28\%) and is part of personal fulfilment (26\%). For widowers, $19.4 \%$ also agree that it is more than a way of earning a living, with $30.6 \%$ saying it is also a way of personal fulfilment.

\subsubsection{Question 3: If you work. What amount of money would allow you to stop working?}

Regarding the third question, 9 tree codes were created. The data shows that $16.9 \%$ would never stop working. Of the remainder, $23 \%$ say that if they had an income between 500 and 1,000 euros they would stop working; $17.7 \%$ say that to stop working they would need a monthly income between 1,000 and 1,500 euros and $14.8 \%$ between 1,500 and 2,500 euros. On the other hand, only $2.5 \%$ of respondents would stop working if they had an income below 500 euros. Above 2,500 and up to 3,500 is indicated by $7.8 \%$; between 3,500 euros and 4,500 euros by $1.2 \%$ and above 4,500 euros by $6.6 \%$ of respondents. The analysis of the answers to the 3rd question by sex (Graph 7), shows that there is a great proximity between sexes, in relation to never stopping working; $17.3 \%$ of men and $16.7 \%$ would never stop working whatever their income. Regarding the values that each sex mentioned that with which they would stop working, there are some differences: For income of up to 1,500 euros, only $28.4 \%$ of men would stop working, as opposed to women $(50.6 \%)$. For values between 1,500 euros and 2,500 euros, $18.5 \%$ of men say they would stop working and $13 \%$ of women. The age analysis of the respondents (Graph 8 ) shows that $55.9 \%$ of individuals aged between 19 and 25 years old would stop working with an income below 1,500 euros; for that same value, in the age group between 25 and 35 it reduces to $50.9 \%$; in the $36-49$ age group, $36 \%$ would stop working if they had an income of up to 1,500 euros and $37.1 \%$ of the age group of 50 and over. Regarding the analysis by respondents' marital status, while $20.9 \%$ of married or unmarried partners would never stop working and $15.5 \%$ of singles, while only $3.6 \%$ of divorcees express this opinion. With regard to the amounts of money they would need to stop working, the answers are different: for $35.7 \%$ of singles, less than 1,000 euros per month would suffice; this value for married couples would only attract $20.9 \%$ and $17.9 \%$ of divorcees. 


\subsubsection{Question 4: If you work. What was the most useless task (job) you have ever performed in your professional life?}

Regarding the 4th question, of the 273 respondents, 140 reported having already performed unnecessary work in their professional lives (51.4\%). Of these, 59.3\% were reported by female respondents and $40.7 \%$ by male respondents. In the analysis by age, it is clear that as age advances (up to 50 years), the opinion about useless jobs also increases: $12.1 \%$ up to 25 years old; $22.1 \%$ between 26 and 35 years old and $36.4 \%$ between 36 and 49 years old; over the age of 50 , this value reduces to $28.6 \%$. When analysing the results by marital status, it is noticed that there are significant differences because while divorcees report $13.6 \%$ of useless jobs and singles, $34.3 \%$, the majority, 51.4\%, of married people report the same opinion: In the tables below, we highlight some of the references noted by respondents. In table 8 , as we can see, there are several indications that reveal problems with managers and leaders, which add up to almost $10 \%$ of the total observations.

In table 2, we report the references to useless jobs that are related to wasting time; there are several comments about "useless meetings" in the opinion of the respondents as well as the dead time in companies.

\section{Table 2 - Selected references}

\begin{tabular}{|lll|}
\hline \multicolumn{4}{|c|}{ Observations about useless jobs - wasting time } \\
\hline 1 & Reference 21 & $\begin{array}{l}\text { Meeting presentations that were never seen. Preparation of repetitive documents } \\
\text { with no added value. }\end{array}$ \\
\hline 2 & Reference 42 & Being inside a store waiting for customers to enter \\
3 & Reference 44 & Training time or completely useless meetings \\
4 & Reference 72 & Staying at work having no customers to serve \\
\hline 5 & Reference 74 & "Dead" times with no customers \\
6 & Reference 78 & Doing tasks a few minutes before finishing time. \\
\hline 7 & Reference 85 & Wasting hours in useless meetings \\
\hline
\end{tabular}

Finally, in Table 3 we present some references related to personal observations about jobs considered useless by the respondents:

\section{Table 3 - Selected references}

\begin{tabular}{|ccc|}
\hline \multicolumn{2}{|c|}{ Observations about useless jobs - Functions } \\
\hline 1 & Reference 76 & $\begin{array}{l}\text { Counting } 5000 \text { advertising pamphlets to certify that the company was not being } \\
\text { cheated!!!! }\end{array}$ \\
2 & Reference 95 & Idon't know, I work for the State, so there are several useless situations. \\
3 & Reference 99 & $\begin{array}{l}\text { Working for the extremely heavy and grinding machine called "the State" where } \\
\text { there is no meritocracy }\end{array}$ \\
4 & Reference 103 & Bringing coffee to people when I have a master's in marketing management \\
\hline
\end{tabular}

The data allows us to highlight that two of the references are directed to public services and, according to their authors, to the lack of meritocracy and the uselessness of various situations; the other two refer to situations related to the functions performed by the authors. 
In general, the results of the qualitative analysis allow us to infer that there are still many flaws to resolve with regard to the management and leadership of human resources.

Among other aspects, the qualitative analysis allows us to infer that, in general, the respondents would prefer to work even though they could possibly receive a UBI. At the same time, it appears that there is no clear awareness of the implications of the $\mathrm{UBI}$ and that there is a great variation in the value that respondents understand as the minimum value to not need to work.

Finally, it should be noted again that the results of this qualitative study complement other quantitative articles on the same theme published by the authors ${ }^{1}$.

\section{Final considerations}

Technological advances, together with demographic changes, globalisation and work organisation, have changed the structure and nature of work. Technological developments, namely in terms of digital transformation and robotization, open up space for the development of new sectors of work, but also raise growing concerns about future job losses. The question of how to maintain balanced living conditions for all is inextricably linked to these global trends, especially for those whose jobs may be more negatively affected by advances in technology. The UBI therefore appears as a possible solution to this growing problem. The solution is considered attractive, as it could help support social, environmental, cultural areas, etc. also acting in the key areas of personal development and being able to generate positive synergies, such as the free choice of individual activities, flexibility in employment and promotion of the entrepreneurial spirit, in addition to providing support for the basic rights that each citizen should have.

However, the UBI has other implicit problems as it may be seen as a negative incentive for work (due to the current parameters) and will imply the allocation of financial resources that are incalculable at this stage. It is too early to study a possible performance of the UBI in global terms, since most pilot projects, on the one hand, cannot be considered universal and unconditional and, on the other hand, some are only in the initial stages of implementation.

The results of the qualitative analysis of the survey on the work of the future and the future of work and the perception of the UBI allow us to infer, as indicated in the previous chapter, that there is no clear notion about the UBI or its implications, so from our point of view it is essential and urgent to launch the debate in Portugal at the academic level; this must be done in a careful and objective way, based on literature and approaches by international researchers, as well as on studies and

\footnotetext{
${ }^{1}$ Rendimento Básico Incondicional - A perceção em Portugal. Available at: https://www.finersistemas.com/atenaeditora/index.php/admin/api/ebookPDF/3026?fbclid=IwAR0X7Bhl_2Ri75BJFIZ3leQUU7x304vHNv7QyTOuWCz7QhlyHJLX_YrPu8. Accessed on: 19/02/2020.
} 
results of previous experiences, some of which are presented in a summary form in this study.

\section{Bibliography}

[1] Ackerman, B. A., \& Alstott, A. (1999). The stakeholder society. Yale University Press.

[2] Altinay, L., \& Paraskevas, A. (2008). Planning research in hospitality and tourism. Oxford ; Burlington, Mass. : Butterworth-Heinemann.

[3] Altman, J. (2016). Basic Income for Remote Indigenous Australians:

Prospects for a Livelihoods Approach in Neoliberal Times. In Basic Income in Australia and New Zealand (pp. 179-205). New York: Palgrave Macmillan US. https://doi.org/10.1057/9781137535320_9

[4] Altman, J., \& Markham, F. (2019). Basic Income and Cultural Participation for Remote-Living Indigenous Australians (pp. 87-109). https://doi.org/10.1007/978-3-030-14378-7_5

[5] Alzúa, M. L., Cruces, G., \& Ripani, L. (2013). Welfare programs and labour supply in developing countries: experimental evidence from Latin America. Journal of Population Economics, 26(4), 1255-1284.

https://doi.org/10.1007/s00148-012-0458-0

[6] Arendt, H. (2010). A condição humana. Forense Universitaria.

[7] Aydinonat, N. E. (2015a). Dani Rodrik's Economics rules: the rights and wrongs of the dismal science. New York: W. W. Norton \& Company, 2015, 272 pp. Erasmus Journal for Philosophy and Economics, 8(2), 94. https://doi.org/10.23941/ejpe.v8i2.203

[8] Aydinonat, N. E. (2015b). Dani Rodrik's Economics rules: the rights and wrongs of the dismal science. New York: W. W. Norton \& Company, 2015, 272 pp. Erasmus Journal for Philosophy and Economics, 8(2), 94. https://doi.org/10.23941/ejpe.v8i2.203

[9] Bagus, P., \& Howden, D. (2010). Munich Personal RePEc Archive Causes and Consequences of Inflation Causes and Consequences of Inflation 1. https://doi.org/10.1111/basr.12043/abstract

[10] Berrios, L. A., \& Santos, J. A. (2013). Impactos da inflação no poder de compra do salário mínimo: um breve panorama. Revista de Administração Do Unisal, 74-91.

[11] Bessa, D. (2006). Teorias explicativas da inflação: apreciação crítica* 1.0 PROCESSO INFLACIONADO: REALIDADE DE LOCALIZA-ÇÃO HISTÓRICA PRECISA. Análise Social (Vol. XVI).

[12] Birnbaum, S. (2012). Equality of Status and Its Priority: A Rawlsian Case for Basic Income. In Basic Income Reconsidered (pp. 41-63). New York: Palgrave Macmillan US. https://doi.org/10.1057/9781137015426_2 
[13] Blankenagel, W. (2012). Geschichte des Grundeinkommens. Books on Demand.

[14] Burns, E. M. (2011). A Revolução Industrial dos séculos XIX e XX Consciência.org. Retrieved November 3, 2019, from http://www.consciencia.org/a-revolucao-industrial-dos-seculos-xix-e-xx

[15] Chandra, P., Chandra, \& Pasma. (2010). Working Through the Work Disincentive. Basic Income Studies, 5(2), 1-20.

[16] Charlier, J. (1848). Solution du problème social ou Constitution humanitaire, basée sur la loi naturelle et précédée de l'exposé des motifs - Google Play. Bruxelles.

[17] Condorcet, J.-A.-N. de C. marquis de. (1795). Esquisse d'un tableau historique des progres de l'esprit humain. Ouvrage posthume de Condorcet. https://doi.org/10.1017/CB09781107415324.004

[18] Costa, A. P. (2016). Cloud Computing em Investigação Qualitativa: Investigação Colaborativa através do software webQDA. Fronteiras: Journal of Social, Technological and Environmental Science, 5(2), 153. https://doi.org/10.21664/2238-8869.2016v5i2.p153-161

[19] Costa, A. P., \& Amado, J. (2018). Content Analysis Supported by Software. Aveiro: Ludomédia. Retrieved from https://www.ludomedia.pt/en/prod_details.php?id=172\&catId=13\&offset= 0

[20] Costa, A. P., de Sousa, F. N., Moreira, A., \& de Souza, D. N. (2017). Research through Design: Qualitative Analysis to Evaluate the Usability (pp. 1-12). https://doi.org/10.1007/978-3-319-43271-7_1

[21] Costa, A. P., de Souza, F. N., Moreira, A., \& de Souza, D. N. (2018). webQDA 2.0 Versus webQDA 3.0: A Comparative Study About Usability of Qualitative Data Analysis Software (pp. 229-240). https://doi.org/10.1007/978-3-31958965-7_16

[22] Costa, A. P., Linhares, R., \& de Souza, F. N. (2014). Possibilidades de Análise Qualitativa no webQDA e colaboração entre pesquisadores em educação em comunicação. In R. Linhares, S. de L. Ferreira, \& F. T. Borges (Eds.), Infoinclusão e as possibilidades de ensinar e aprender (pp. 205-215). Universidade Tiradentes, Aracaju - Brazil: Editora da Universidade Federal da Bahia.

[23] Costa, A. P., Moreira, A., \& Souza, F. N. (2019). webQDA - Qualitative Data Analysis. Aveiro - Portugal: Aveiro University and MicroIO. Retrieved from www.webqda.net

[24] Denniss, R., \& Swann, T. (2016). Consumption Smoothing with Basic Income: The Role of Administrative Loans. In Basic Income in Australia and New 
Zealand (pp. 115-132). New York: Palgrave Macmillan US. https://doi.org/10.1057/9781137535320_6

[25] Dowding, K., Wispelaere, J. De, \& White., S. (2003). The Ethics of Stakeholding. New York: Palgrave Macmillan.

[26] Europeu, B. C. (2009). A estabilidade de preços é importante porquê?

[27] Figueiredo, M. A. de. (2013). Será que os surfistas devem ser subsidiados? e se no futuro os nossos impostos pagarem um rendimento garantido a todos, igual para pobres ou ricos, preguiçosos ou viciados no trabalho? Alêtheia Editores.

[28] FitzRoy, F., \& Jin, J. (2018). Basic income and a public job offer: complementary policies to reduce poverty and unemployment. Journal of Poverty and Social Justice, 26(2), 191-206. https://doi.org/10.1332/175982718X15200701225179

[29] Flomenhoft, G. (2017). Total Economic Rents of Australia as a Source for Basic Income. In Financing Basic Income (pp. 77-100). Springer International Publishing. https://doi.org/10.1007/978-3-319-54268-3_4 [30] Foner, E. (1995). Thomas Paine : collected writings. Library of America.

[31] Fourier, C. (1836). La fausse industrie, morcelée, répugnante, mensongère, et l'antidote.

[32] Frank, R. H. (2008). Context Is More Important Than Keynes Realized. In Revisiting Keynes (pp. 143-150). The MIT Press. https://doi.org/10.7551/mitpress/9780262162494.003.0011

[33] Friedman, M. (2009). Capitalism and Freedom: Fortieth Anniversary Edition: Fortieth Anniversary Edition (Google eBook). University of Chicago Press.

[34] García, J. A., \& Werner, T. (2010). Working PaPer Serie S - n 1162 InFLation riSkS and InFLation riSk PreMia. Retrieved from http://www.ecb.europa.eu

[35] Goldsmith, S. (2012). The Economic and Social Impacts of the Permanent Fund Dividend on Alaska. In Alaska's Permanent Fund Dividend (pp. 49-63). New York: Palgrave Macmillan US. https://doi.org/10.1057/9781137015020_4

[36] Groot, L., Muffels, R., \& Verlaat, T. (2019). Welfare States' Social Investment Strategies and the Emergence of Dutch Experiments on a Minimum Income Guarantee. Social Policy and Society, 18(2), 277-287. https://doi.org/10.1017/S1474746418000283

[37] Guilherme De Moura, E., \& Florianópolis, P. (2006). UNIVERSIDADE FEDERAL DE SANTA CATARINA CENTRO DE FILOSOFIA E CIÊNCIAS HUMANAS Programa de Pós-Graduação em História A posição política da Igreja Presbiteriana do Brasil (IPB) nos anos de chumbo (1964-1985). 
[38] Henrique, P., \& Mota, P. (2016). A noção de essência humana no jovem Marx The notion of human essence in the young Marx. Retrieved from www.marilia.unesp.br/filogenese

[39] Hollo, T. (2019). Finding a Political Strategy for a Basic Income in Australia (pp. 129-145). https://doi.org/10.1007/978-3-030-14378-7_7

[40] Huws, U. (2017). Where Did Online Platforms Come From? The Virtualization of Work Organization and the New Policy Challenges it Raises. In Policy Implications of Virtual Work (pp. 29-48). Cham: Springer International Publishing. https://doi.org/10.1007/978-3-319-52057-5_2

[41] Jordan, B. (2010). Basic Income and Social Value. Basic Income Studies, 5(2). https://doi.org/10.2202/1932-0183.1140

[42] Jörimann, A. (2017). Financing Basic Income in Switzerland, and an Overview of the 2016 Referendum Debates. In Financing Basic Income (pp. 49-74). Cham: Springer International Publishing. https://doi.org/10.1007/978-3-319-54268-3_3

[43] Kaighin, J. (2019). What About Young People? Why a Basic Income for Young People Matters (pp. 179-198). https://doi.org/10.1007/978-3-030-143787_10

[44] Marcelo, G., Merrill, R., Bizarro, S., \& Pinto, J. (2019). Rendimento Básico Incondicional: uma defesa da liberdade. Leya.

[45] Marston, G. (2016). Greening the Australian Welfare State: Can Basic Income Play a Role? In Basic Income in Australia and New Zealand (pp. 157-177). New York: Palgrave Macmillan US. https://doi.org/10.1057/9781137535320_8

[46] Mays, J. (2016). Disability, Citizenship, and Basic Income: Forging a New Alliance for a Non-disabling Society. In Basic Income in Australia and New Zealand (pp. 207-251). New York: Palgrave Macmillan US. https://doi.org/10.1057/9781137535320_10

[47] Mill, J. S. (2006). Principles of political economy. Cosimo Classics.

[48] More, T. (2014). Utopia. Brasilia: Instituto de Pesquisa de Relações Internacionais_Editora Universidade de Brasl1ia_.

[49] Pech, W. J. (2010). Behavioral Economics and the Basic Income Guarantee. Basic Income Studies, 5(2). https://doi.org/10.2202/1932-0183.1167

[50] Pereira, R. (2017a). Introduction: Financing Approaches to Basic Income. In Financing Basic Income (pp. 1-5). Cham: Springer International Publishing. https://doi.org/10.1007/978-3-319-54268-3_1

[51] Pereira, R. (2017b). The Cost of Universal Basic Income: Public Savings and Programme Redundancy Exceed Cost. In Financing Basic Income (pp. 9-45). Cham: Springer International Publishing. https://doi.org/10.1007/978-3319-54268-3_2 
[52] Pound, E., Davis, M. T., \& McWhirter, C. (2015). Ezra Pound and Globe magazine : the complete correspondence.

[53] Quiggin, J. (2019). Basic or Universal? Pathways for a Universal Basic Income (pp. 147-161). https://doi.org/10.1007/978-3-030-14378-7_8

[54] Rifkin, J. (2014). A Terceira Revolução Industrial. Bertrand Editora.

[55] Rodrik, D. (2015). Economics Rules: The Rights and Wrongs of the Dismal Science (an excerpt). Journal of Economic Sociology, 16(4), 39-59. https://doi.org/10.17323/1726-3247-2015-4-39-59

[56] Russell, B. (2004). Proposed roads to freedom. Cosimo Classics.

[57] Silva, A. S. da. (2016). DESTINO, HUMILHAÇÃO E DIREITO: A REINVENÇÃO NARRATIVA DA COMUNIDADE -Volume 2. Universidade de Coimbra.

[58] Tobin, J. (1980). Asset accumulation and economic activity reflections on contemporary macroeconomic theory. Chicago: University of Chicago Press.

[59] Ursula Huws. (2016). Logged labour: a new paradigm of work organisation? Work Organisation, Labour \& Globalisation, 10(1), 7. https://doi.org/10.13169/workorgalaboglob.10.1.0007

[60] Van Donselaar, G. (2009). The Right to Exploit: Parasitism, Scarcity, and Basic Income. The Right to Exploit: Parasitism, Scarcity, and Basic Income. Oxford University Press.

https://doi.org/10.1093/acprof:oso/9780195140392.001.0001

[61] Van Parijs, P. (2004). Basic Income: A Simple and Powerful Idea for the Twenty-first Century. In Politics and Society (Vol. 32, pp. 7-39). SAGE Publications Inc. https://doi.org/10.1177/0032329203261095

[62] Vives, J. L. (2017). Tratado Del Socorro De Pobres: De Subventione Pauperum. Madrid: Pré textos.

[63] Widerquist, K. (2001). Perspectives on the Guaranteed Income, Part I. Journal of Economic Issues, 35(3), 749-757.

https://doi.org/10.1080/00213624.2001.11506401

[64] Widerquist, K. (2018). Why UBI Experiments Cannot Resolve Much of the Public Disagreement About UBI. In A Critical Analysis of Basic Income Experiments for Researchers, Policymakers, and Citizens (pp. 87-91). Cham: Springer International Publishing. https://doi.org/10.1007/978-3-03003849-6_11

[65] Wray, L. R. (2013). The Euro Crisis and the Job Guarantee: A Proposal for Ireland. In The Job Guarantee (pp. 161-177). New York: Palgrave Macmillan US. https://doi.org/10.1057/9781137297990_8

[66] Yunker, J. A. (2013). The Basic Income Guarantee: A General Equilibrium Evaluation. Basic Income Studies, 8(2). https://doi.org/10.1515/bis-20130014 
[67] Zhen, Y., Guerriero, M., Lopez, E., \& Haverman, P. (2020). Universal Basic Income: A Working Paper A Policy Option for China beyond 2020? UNVP China. 